\title{
The use of two operants to examine the nature of pimozide-induced decreases in responding for brain stimulation
}

\author{
RICHARD J. BENINGER and NELSON L. FREEDMAN \\ Queen's University, Kingston, Ontario, Canada
}

\begin{abstract}
Although a number of researchers have suggested that the brain's dopaminergic neurons mediate the behavioral effects of reinforcement, others have argued that many of the observed behavioral effects of blocking dopaminergic receptors can be attributed to motor deficits. To decide between these alternatives, rats were trained to leverpress and run in a wheel for brain stimulation reinforcement in daily two-session training periods. They then were tested with the dopamine receptor blocker, pimozide $(1.0 \mathrm{mg} / \mathrm{kg})$; rats receiving leverpress testing in both sessions responded significantly less in the second session than did rats tested on the sequence of wheel-lever. These results support the hypothesis that pimozide interferes with the reinforcement process rather than simply producing motor deficits.
\end{abstract}

Recently, a number of authors have reported data supporting the hypothesis that the reinforcing effects of electrical stimulation of the brain (ESB) and food are mediated in part by central neurons utilizing dopamine as a neurotransmitter (see review by Wise, 1982). For example, it has been found that animals responding for food or ESB undergo an extinctionlike decrease in responding when injected with dopamine receptor-blocking drugs (Beninger, 1982; Fouriezos, Hansson, \& Wise, 1978; Mason, Beninger, Fibiger, \& Phillips, 1980; Wise, Spindler, deWit, \& Gerber, 1978; Wise, Spindler, \& Legault, 1978).

Others have challenged this position, arguing that the apparent extinction-like pattern of responding does not preclude a motor deficit in animals with dopamine function disrupted (Ettenberg, Cinsavich, \& White, 1979; Ettenberg, Koob, \& Bloom, 1981; Phillips \& Fibiger, 1979). It has been suggested that a motor deficit may not be manifest until responses have been performed under the influence of the drug; for example, the drugged animal might be easily fatigable (cf. Beninger \& Phillips, 1980; Mason et al., 1980). If this hypothesis is correct, the pattern of responding of animals with DA function disrupted, although similar to the pattern normally seen in extinction, would not reflect a specific effect on reinforcement.

This research was supported by grants from the Medical Research Council to R.J.B. and from the Natural Sciences and Engineering Research Council to N.L.F. We wish to thank Maxine Derrah for her excellent technical assistance. Pimozide was generously supplied by Albert Wauquier of Janssen Pharmaceutica. R.J.B. is an Ontario Ministry of Health Career Scientist. Reprints can be obtained from R. J. Beninger at Department of Psychology, Queen's University, Kingston, Ontario K76 3N6, Canada.
The present experiment undertook to pit the hypothesis that blockade of dopamine neuronal function results in a blockade of the reinforcement process against the hypothesis that this treatment results in motoric impairments through increased fatigability. This was done by first training animals to perform two distinct operants at similar rates, each in a distinct stimulus situation; thus, animals were trained to leverpress in a test chamber and run in a wheel for ESB. Then, on test days, the animals were injected with a dopamine receptor blocker and given two sessions, one immediately following the other; two sequences of sessions were employed: lever-lever and wheel-lever. The comparison of interest was the leverpress rate in the second session following a lever session vs. that rate following a wheel session.

According to the hypothesis that dopamine mediates the effects of reinforcement, responding in the second (lever) session should be less following a lever session than following a wheel session. This would occur because the conditioned incentive (responseeliciting) properties of stimuli associated with the lever environment would be weakened following a session there without reinforcement (see Bindra, 1974, 1978); following a wheel session under the influence of the drug, however, the stimuli associated with the lever environment would retain strong incentive properties and more responding should be observed.

The alternative possibility is that responding in the second (lever) session will be at the same level in the drugged rats regardless of the operant environment in the first session. This finding would be consistent with the hypothesis that dopamine-receptor-blocking drugs produce a motor deficit characterized by increased fatigability. Thus, performance of either 
wheel-running or leverpress operants under the influence of a dopamine blocker leads to fatigue, resulting in decreased leverpressing in the second session.

\section{METHOD}

\section{Subjects}

Male albino rats of the Wistar strain, weighing from 250 to $300 \mathrm{~g}$ at the beginning of the experiment, were housed individually in a climatically controlled colony room kept on a 12-h light $(0600$ to $1800 \mathrm{~h}$ )/dark cycle. Food and water always were available in the home cage.

\section{Surgery and Histology}

After anesthetization with an ip injection of pentobarbital sodium $(50 \mathrm{mg} / \mathrm{kg})$, each rat was implanted stereotaxically with a bipolar electrode made of intertwisted stainless steel wires $.25 \mathrm{~mm}$ in diameter and insulated except at the tip (Plastic Products MS 303-0.010). With the surface of the skull approximately horizontal, coordinates of $3.5 \mathrm{~mm}$ posterior to bregma, $1.5 \mathrm{~mm}$ lateral to the midline, and $8.5 \mathrm{~mm}$ below the surface of the skull were used with the lateral hypothalamus as the target. At least 7 days of recovery from surgery preceded the initiation of testing.

Following completion of the experiment, the rats were killed and perfused through the heart with saline followed by $10 \%$ Formalin. Brains were extracted, fixed in 10\% Formalin, sliced at $30 \mu \mathrm{m}$, and stained with thionin to verify electrode loci.

\begin{abstract}
Apparatus
There were two distinct experimental environments. Leverpress training was carried out in two similar Plexiglas cubicles $(31 \times$ $16 \times 35 \mathrm{~cm}$ high) with grid floors and a lever $(10 \mathrm{~cm}$ wide) located in the middle of one of the $16-\mathrm{cm}$ end walls at a height of $5 \mathrm{~cm}$. Running was tested in two similar 35-cm-diam unidirectional wheels constructed of Plexiglas sides with grid floors. For further details, see Lyons and Freedman (1982). Each apparatus was located in an insulated wooden box that was open on the front for easy viewing and could be observed from an adjacent room via a window.

ESB was administered through leads attached to a mercury slipring, thereby allowing the rats freedom of movement. Each reinforcement consisted of a 300 -msec train of sinusoidal electrical stimulation presented at a frequency of $60 \mathrm{~Hz}$, the current varying from rat to rat and ranging from 90 to $110 \mu \mathrm{A}$. The current was kept constant by placing a large resistance in series with the rat. Solid-state switching and timing devices (BRS/LVE) were used to control the presentation of ESB and to record the data.
\end{abstract}

\section{Procedure}

Rats were screened for self-stimulation in the lever and wheel apparatuses, and 12 were selected for further training. Training procedures were designed so that each rat would receive equal exposure to each apparatus and would respond at an equal rate in each apparatus, and so that the apparatus encountered each session would be unpredictable. Thus, at approximately the same time each day, each rat received two 15-min sessions, one immediately succeeding the other. Each day, one of four sequences was followed: wheel-wheel, wheel-lever, lever-wheel, or leverlever. During a wheel session, each 15-deg turn was defined as a response and produced one ESB; in the lever sessions, each leverpress produced one ESB. This resulted in an equal number of reinforcements in each apparatus. Between the first and second session each day, the rat was disconnected from the lead and returned to its home cage and then immediately returned and reconnected to the same or alternate apparatus, depending on the sequence for that day. In a 4-day period, each rat received one of each sequence, but the order was random. All rats received a total of 12 training days; thus, each had each sequence a total of three times and equal experience with both apparatuses. The dependent variable was number of responses.
Testing took place on the following 2 days. Four hours prior to testing on each day, each rat received an ip injection of the dopamine receptor blocker (Anden, Butcher, Corrodi, Fuxe, \& Ungerstedt, 1970) pimozide (1 mg/kg) dissolved in boiling tartaric acid $(40 \mu \mathrm{mol} / \mathrm{ml})$ and cooled to room temperature prior to injection. The dose selected has been shown repeatedly to produce an extinction-like decrease in operant responding (Fouriezos et al., 1978; Wise, 1982). On the first day, six rats received the sequence wheel-lever and six received lever-lever. On the second day, each rat received the sequence that it had not received on the first. The comparison of interest was the rate in the second (lever) session following a lever session vs. the rate following a wheel session.

\section{RESULTS}

Histological results for 10 rats are shown in Figure 1; the brains of the remaining two rats were damaged because of technical problems. In general, the electrodes were located in the lateral hypothalamic area in or dorsal to the medial forebrain bundle. These sites frequently have been shown to support self-stimulation and to be sensitive to manipulations affecting dopaminergic neurotransmission (Fouriezos et al., 1978).

Leverpress results are shown in Figure 2. Mean ( \pm SEM) baseline rates were calculated over the last 8 training days. There were four occasions when the lever occurred in the first session (open bar); there were two occasions when the lever occurred in the second session following a lever session (solid bar) and two when lever followed wheel (crosshatched bar). As the figure indicates, mean baseline lever response rates were remarkably consistent regardless of the session (first or second) or sequence (lever-lever or wheel-lever). Mean ( \pm SEM) leverpress rates during the first session on the 2 pimozide days also are shown in Figure 2 (open bar to right) and clearly were decreased from baseline levels. When the second session also was a lever session, mean ratios similarly were depressed (solid bar to right). However, when the second (lever) session followed a wheel session (cross-hatched bar to right), mean lever rates were significantly higher than those seen when the second (lever) session followed a lever session $[t(11)=2.33, p<.05]$.

Wheel-turning rates are not shown in the figures. The mean $( \pm$ SEM) 15-deg wheel turns per minute during baseline in the first session was $68.6( \pm 10.9)$, and in the second session after lever was $72.3( \pm 11.1)$ and after wheel was 65.4 ( \pm 10.8$)$; clearly, these rates do not differ significantly from baseline leverpress rates, and, as in the case of leverpressing, mean wheel rates were remarkably invariant during baseline. During the first session on the 2 pimozide days, mean wheel rates were $43.8( \pm 10.9)$, showing that pimozide produced a decrease in wheel running, as it did in leverpressing. Furthermore, these first-session wheel rates did not differ significantly from the firstsession lever rates on the 2 pimozide days $[t(11)=$ $1.80, \mathrm{p}>.05]$. 


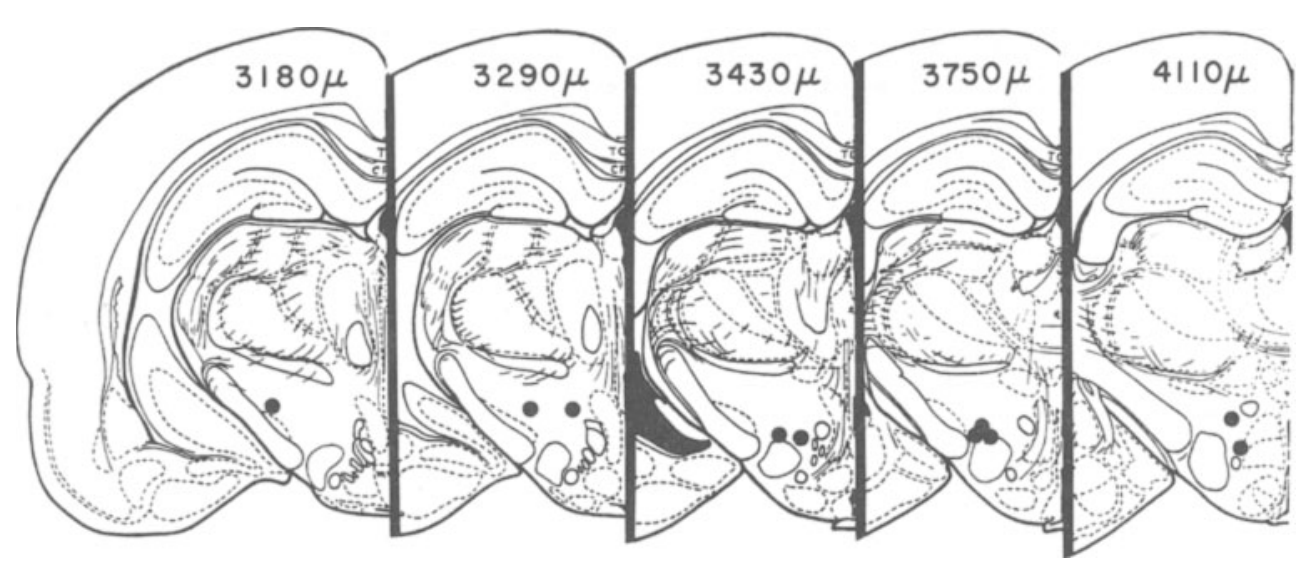

Figure 1. Location of electrode tips for 10 rats plotted on drawings from König and Klippel (1963). Numbers on the top of each section indicate the distance in micrometers anterior to the interaural line.

\section{DISCUSSION}

The results showed that the effects of pimozide on leverpressing for ESB were significantly less when the preceding session was wheel running than when it was leverpressing. This difference cannot be attributed to the activating effects of differential handling, since each day all rats were disconnected and removed from the test apparatus following Session 1 and then reconnected for Session 2, regardless of the sequence. It remains possible that in the first session on the 2 drug days, wheel running while under the influence of pimozide was less fatigable than leverpressing and that this difference produced the differential effect on leverpressing in the second session; however, as this difference was not significant and the two operants were equated to produce similar rates in both apparatuses in the predrug sessions, this explanation of the data seems unlikely.

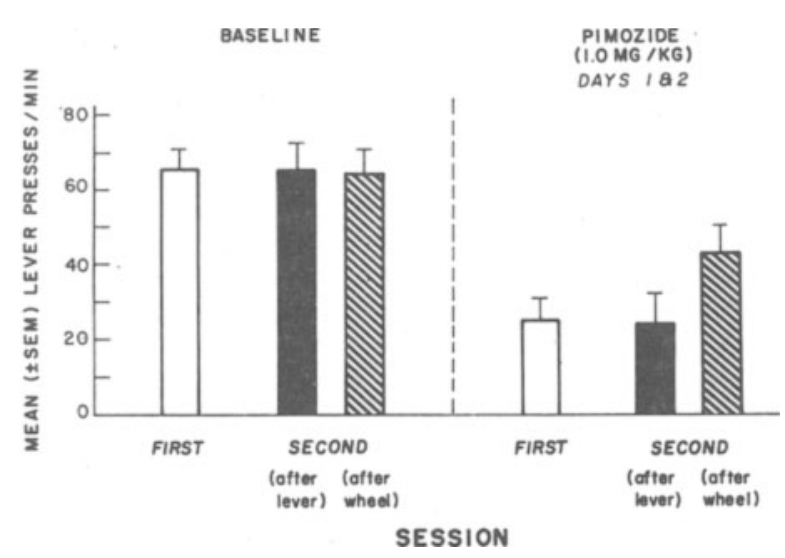

Figure 2. Mean ( \pm SEM) leverpress rate (responses/minute) durIng the first 8 training days (baseline) and the 2 pimoxide teat days. The open bar represents the first 15-min session of leverpressing. The solld bar represents leverpressing in the second 15 -min session when it followed a leverpressing session; the cross-hatched bar represents leverpressing in the second session when it followed wheel turning. $\mathbf{N}=12$.
The results support the hypothesis that dopaminergic neurons form a critical link in the neuronal circuitry that mediates the effects of reinforcement on behavior. It often has been suggested that the effects of reinforcement are to increase the incentive properties of environmental stimuli associated with it (Bindra, 1974, 1978). Accordingly, during wheel and lever training with ESB reinforcement, stimuli in both environments become conditioned incentive stimuli, acquiring an ability to elicit responses. When dopaminergic receptors are blocked with pimozide, these conditioned incentive stimuli can maintain responding transiently but lose this ability with repeated testing. Thus, conditioned incentive stimuli in the lever environment were weakened during the initial lever session with pimozide, and less responding occurred in the second (lever) session than did in the second session with similarly drugged animals exposed to a different set of conditioned incentive stimuli (wheel environment) in the first session.

The present results are in agreement with those reported by Franklin and McCoy (1979). These authors trained rats to initiate responding for ESB when either of two distinct stimuli was presented. When responding had stabilized, animals were injected with pimozide and observed to show an extinction-like decline in responding in the presence of one of the stimuli; the second stimulus was then presented and responding was seen to be reinstated for a time. Thus, previously established incentive stimuli can elicit responses in pimozide-treated rats that have ceased to respond. These findings and those from the present study provide further evidence that dopaminereceptor-blocking drugs do not simply produce a motoric deficit; rather, these drugs impair the usual effects of reinforcement on behavior.

\section{REFERENCES}

Anden, N. E., Butcher, S. G., Corrodi, H., Fuxe, K., \& UNGERSTEDT, U. Receptor activity and turnover of dopamine 
and noradrenaline after neuroleptics. European Journal of Pharmacology, 1970, 11, 303-314.

Beninger, R. J. A comparison of the effects of pimozide and nonreinforcement on discriminated operant responding in rats. Pharmacology, Biochemistry and Behavior, 1982, 16, 667-669.

Beninger, R. J., \& Phillips, A. G. The effect of pimozide on the establishment of conditioned reinforcement. Psychopharmacology, 1980, 68, 147-153.

Bindra, D. A motivational view of learning, performance and behavior modification. Psychological Review, 1974, 81, 199-213.

Bindra, D. How adaptive behavior is produced: A perceptualmotivational alternative to response-reinforcement. Behavioral and Brain Sciences, 1978, 1, 41-91.

Ettenbera, A., Cinsavich, S. A., \& White, N. A. Performance effects with repeated-response measures during pimozideproduced dopamine receptor blockade. Pharmacology, Biochemistry and Behavior, 1979, 11, 1-5.

EttenberG, A., Коов, G. F., \& Bloom, F. E. Response artifact in the measurement of neuroleptic-induced anhedonia. Science, 1981, 213, 357-359.

Fouriezos, G., Hansson, P., \& Wise, R. A. Neuroleptic induced attenuation of brain stimulation reward in rats. Journal of Comparative and Physiological Psychology, 1978, 92, 661-671.

Frankurn, K. B. J., \& McCoy, S. N. Pimozide-induced extinction in rats: Stimulus control of responding rules out motor deficit. Pharmacology, Biochemistry and Behavior, 1979, 11, 71-75.
König, J. F. R., \& KLIPPEL, R. A. The rat brain. Baltimore: Williams \& Wilkins, 1963.

Lyons, H. I., \& Freedman, N. L. Task-dependent properties of brain stimulation reward. Behavioral Brain Research, 1982, 4, 339-358.

Mason, S. T., Beninger, R. J., Fibiger, H. C., \& Phillips, A. G. Pimozide-induced suppression of responding: Evidence against a block of food reward. Pharmacology, Biochemistry and Behavior, 1980, 12, 917-923.

Phillips, A. G., \& Fibiger, H. C. Decreased resistance to extinction after haloperidol: Implications for the role of dopamine in reinforcement. Pharmacology, Biochemistry and Behavior, $1979,10,751-760$.

Wise, R. A. Neuroleptics and operant behavior: The anhedonia hypothesis. Behavioral and Brain Sciences, 1982, 5, 39-88.

Wise, R. A., Spindler, J., deWit, H., \& Gerber, G. J. Neuroleptic-induced "anhedonia" in rats: Pimozide blocks the reward quality of food. Science, 1978, 201, 262-264.

Wise, R. A., Spindler, J., \& Legault, L. Major attenuation of food reward with performance-sparing doses of pimozide in the rat. Canadian Journal of Psychology, 1978, 32, 77-85.

(Manuscript received June 28, 1982;

revision accepted for publication October 29, 1982.) 